\title{
Challenges in Operating Micro-Enterprises by African Foreign Entrepreneurs in Cape Town, South Africa
}

\author{
Risimati Maurice Khosa \\ Department of Entrepreneurship and Business Management, Faculty of Business, Cape Peninsula \\ University of Technology, South Africa. Email: khosarm@gmail.com \\ Vivence Kalitanyi \\ Department of Retail Business Management, Faculty of Business, Cape Peninsula \\ University of Technology, South Africa. Email: kalitanyiv@cput.ac.za
}

\section{Doi:10.5901/mjss.2014.v5n10p205}

\begin{abstract}
The primary objective of this study was to discover the challenges in operating micro-enterprises by African foreign entrepreneurs in Cape Town. Literature on immigrant entrepreneurship was reviewed resulting in the discussion of the significance of immigrant entrepreneurship and challenges in operating micro-enterprises. Convenience sampling was employed; consequential in sample of 93 respondents. The study used mixed methods, where data were collected by conducting semi-structured personal interviews and from self-administered questionnaires. The findings show that though xenophobia is not a frequent challenge to African foreign entrepreneurs in Cape Town, it is detrimental to their enterprises. Lack of knowledge of local languages also appears to be a problem. Immigrant-owned micro-enterprises are also affected by sales fluctuations. Competition is a constraint as there are many businesses of the same nature servicing the same market. Obtaining start-up and growth funding is not easy, especially for micro-enterprises ran by African foreign entrepreneurs. Obtaining a business location is also a challenge. High rent and crime are also obstacles to the enterprises. Recommendations of the study are directed to the immigrant entrepreneurs and selected government departments, and are aimed at dealing with challenges in operating micro-enterprises by African foreign entrepreneurs.
\end{abstract}

Keywords: African immigrants; entrepreneurship challenges; SMME; Immigrant entrepreneurship; Cape Town.

\section{Introduction}

African foreign entrepreneurs ${ }^{1}$ in Cape Town and other cities of South Africa are faced with different challenges in running micro-enterprises, some of which are detrimental to their enterprises and may result in some of them ceasing to do business. Xenophobia is one of the notorious challenges faced by African foreign entrepreneurs. This challenge has been experienced in the past few years, resulting in enterprises temporarily stopping doing business, and some to be out of business permanently.

According to South Africa's National Small Business Act 102 of 1996 (South Africa, 1996), micro-enterprises are those entrepreneurial ventures that generate an annual turnover of less than the Value Added Tax (VAT) registration limit of R1 million per annum. Micro-enterprises usually lack formal tax registration, may not adhere to labour legislation and standard accounting procedures, and usually have less than five employees. Micro-enterprises include, amongst others, spaza $^{2}$ shops, cafés, home-based businesses, mini-taxis, small scale construction, and textile manufacturing (South Africa, 2003). The defining line between the micro-enterprises and survivalist enterprises is often blurred (Cupido, 2002). Although survivalist and micro-enterprises are two separate categories, they are often discussed together for convenience under the term informal sector (Co, Groenewald, Mitchell, Nayager, Van Zyl, \& Visser, 2006:10).

Cape Town has a number of African immigrants who have established small businesses in order for them to survive and fill gaps in the market. Kalitanyi and Visser (2010) report that most of these African immigrants come from Somalia, the Democratic Republic of Congo, Zimbabwe, Rwanda, Burundi and Angola. Kalitanyi and Visser (2010) and

1 "African foreign entrepreneur" refers to an individual from the African continent that carries out entrepreneurial activities in his or her host county. In the current study, the host country is South Africa.

2 The term "spaza" is derived from the isizulu language, meaning "hidden"; it emerged in the apartheid era when business opportunities for black entrepreneurs were restricted. 
Ngwema (1988) elucidate further that over 80\% of African immigrants in South Africa have had a minimum of 10 to 12 years of education, and at least $30 \%$ have had some form of tertiary education, or have completed tertiary education.

Doing business in South Africa becomes tough for these entrepreneurs as they are treated differently. Hence this study aims to:

- Find out the impact that xenophobia has on micro-enterprises ran by African foreign entrepreneurs.

- Find out if lack of knowledge of local languages is an obstacle in operating micro-enterprises by African foreign entrepreneurs.

- Find out if African foreign's micro-enterprises are affected by sales fluctuations.

- Ascertain if competition is a constraint to African foreigners who operate micro-enterprises.

- Investigate the extent to which access to capital is a challenge to African foreign entrepreneurs.

- Find out if obtaining business premises is a challenge to African foreign entrepreneurs.

This article is presented in the following format: in the next section, literature on immigrant entrepreneurship is reviewed, followed by the methodology used to carry out the research as well as the presentation of the results and their discussion. In the final section, recommendations, concluding remarks and suggestions for further research are presented.

\section{Literature Review}

This section looks at various definitions employed by scholars to refer to immigrants who carry out entrepreneurial activities in their host countries, importance of immigrant entrepreneurship, as well as different challenges in operating micro-enterprises.

\subsection{Immigrant entrepreneurship}

Venter, Urban and Rwigema (2008:5) and Hisrich and Peters (1998:9) postulate that entrepreneurship is the process of creating something new with value by devoting the necessary time and effort, assuming the accompanying financial, psychic and social risks, and receiving the resulting reward of financial and personal satisfaction and independence.

According to Fatoki and Patswawairi (2012) and Dalhammar (2004), immigrant entrepreneurship is described as the process by which an immigrant establishes a business in a host country (or country of settlement) which is not the immigrant's country of origin. Immigrant entrepreneurship also refers to the entrepreneurship of recent migrants by means of establishing a business enterprise or engaging in self-employment. Tengeh, Ballard and Slabbert (2011:11) define immigrant entrepreneurship as entrepreneurial activities carried by immigrants just after arriving in their host country, either through personal initiative or social networks. The businesses owned and operated by immigrants are therefore referred to as immigrant-owned businesses. Immigrant entrepreneurship associates the new arrivals with their co-ethnic community in their new country of residence (Chand \& Ghorbani, 2011:594).

Ethnic entrepreneurship is generally viewed as comparable to "immigrant entrepreneurship" and the two terms are often employed interchangeably, though a slight difference between the two terms exists (Azmat, 2010; Volery, 2007). Chand and Ghorbani (2011:594) define ethnic entrepreneurship as a set of connections and regular patterns of interactions among people sharing a common national background or migration experience. According to Azmat (2010) and Volery (2007), "immigrants" include the individuals who migrated over the past decades and exclude members of ethnic minority groups who have been living in the country for centuries; the term "ethnic" is a much broader concept and includes immigrants or minorities. Hence, ethnics are likely to be more recognizable and integrated into host country environment than immigrants. Immigrant entrepreneurship thus refers to the early stages in the process of ethnic entrepreneurship (Azmat, 2010).

In addition to immigrant entrepreneurship and ethnic entrepreneurship, Tengeh et al. (2011:11) note that the term "minority entrepreneurs" is also employed to describe immigrants who carry out entrepreneurial activities. Minority entrepreneur thus refers to business ownership by any individual who is not of the majority population.

Azmat (2010) and Dori, Honig and Ginsberg (2006) report that correlated to immigrant entrepreneurship and ethnic entrepreneurship, the term "transnational entrepreneurship" is swiftly gaining currency and is concerned with transnational entrepreneurs who migrate to other countries and simultaneously maintain business links with their home country as well as with host country. According to Henn (2012), the term was probably first used by Poters, Guarnizo and Haller in 2002 who applied it to self-employed immigrants whose business dealings require frequent travel abroad and who depend for the success of their enterprises on their contacts and associates in another country, above all, their 
country of origin.

As mentioned earlier, the term African foreign entrepreneur refers to an individual from the African continent that carries out entrepreneurial activities in his or her host county. In the current study all four terms (immigrant entrepreneur; ethnic entrepreneur; minority entrepreneur; African foreign entrepreneur) will be used interchangeably.

\subsection{Contribution and significance of immigrant entrepreneurship to host countries}

Dana (1995:57) contends that in recent years entrepreneurship has been a chief source of jobs; it has been connected to economic growth and is believed to guide national propensity. It is also extensively recognized that ethnic minority immigrants have a high propensity towards entrepreneurship and contribute to economic development (Basu, 2011:1). Ethnic entrepreneurship is increasingly being acknowledged as a vital vehicle for economic growth and the regeneration of economies (Chand \& Ghorbani, 2011:593). Recent works have highlighted the vital contribution made by immigrant entrepreneurs from India, China and other countries to innovation and job creation (Basu, 2011:1). Chrysostome and Lin (2010:78) assert that in countries that are main destinations for immigrants such as the United States, Canada, the United Kingdom and Australia, immigrant entrepreneurship plays a vital role in economic development. It creates employment through new business enterprise that contributes to wealth creation.

However, in South Africa immigrants are seen to threaten the jobs of locals as well as undermining wages in an economy that has high levels of unemployment, poverty, and income inequality (Fakoti \& Patswawairi, 2012:140; Maharaj, 2002:52). Nevertheless, migrants contribute to the economy by purchasing goods and services, and importing skills. Thus, immigrant entrepreneurship is one of the ways to boost the level of entrepreneurship and lessen unemployment and poverty. A number of scholars have suggested that migrants actually create jobs. Kalitanyi and Visser (2010), in their study of African immigrants in South Africa, discovered that 29/40 (73\%) interviewed immigrant entrepreneurs from Nigeria prefer to employ South Africans, as do 36/40 (90\%) immigrant entrepreneurs from Senegal and 14/20 (70\%) other immigrant entrepreneurs from assorted African countries. A noteworthy number of 19/20 (95\%) interviewed immigrant entrepreneurs from various African countries prefer to employ South Africans. In short, out of 120 African immigrant entrepreneurs interviewed 98 (82\%) employed South Africans. Fakoti and Patswawairi (2012:139) also report that immigrant entrepreneurs employ native South Africans, suggesting that immigrant entrepreneurship can be one of the ways to combat the high unemployment rate in South Africa.

\subsection{Challenges in running micro-enterprises}

According to Azmat (2010), the indistinct geographical boundaries of globalisation and technological advancement result in increased immigrant entrepreneurship. Yet, immigrant entrepreneurs come across challenges resulting from different values, policies, institutional environment, culture and perception of social responsibility in the new country. They are faced with additional challenges in operating micro-enterprises, some of which are detrimental to their enterprises and may lead them to stop doing business. Tengeh (2013:347) adds that limited job opportunities in South Africa push immigrants into developing their own enterprises. Basu (2011:2) believes that many of the market barriers facing ethnic minority immigrant entrepreneurs are similar to those facing small enterprises in general.

\subsubsection{Xenophobia}

Crush and Ramachandran (2009:5) explain that xenophobia is derived from the Greek words "xenos" and "phobos" which mean "strange or foreign" and "phobia" respectively. Xenophobia can be viewed as attitudes, prejudices, and behaviour that reject, exclude and often vilify persons based on the perception that they are outsiders or foreigners to the community, society or national identity. According to the Concise Oxford English dictionary (2004), xenophobia is an intense or irrational dislike or fear of people from other countries.

Landau, Ramjathan-Keogh and Singh (2005) concur that South Africa has become a primary destination and transit point for migrants from throughout the region as a consequence of long-standing patterns of labour migration, conflict and economic hardship in neighbouring countries, and the country's peace and prosperity. Canetti-Nisim and Pedahzur (2003) and Meijerink, Mudde and Van Holsteyn (1998) argue that for many years, the term xenophobia has suffered from a certain degree of vagueness and was mainly used as a collective term for depictions of fear, hate or hostility expressed towards "foreigners" and mostly "ethnic foreigners".

According to Crush (2000) and Human Rights Commission (1999), South Africa has become increasingly xenophobic in recent years, with a large percentage of South Africans perceiving foreigners, especially and almost 
exclusively black foreigners, as dangerous and undesirable. Hunter and Skinner (2003:311) in their study of foreign street traders in inner city Durban report that problems related to xenophobia surface as further challenges to the trading activities. Hunter and Skinner (2003:311) quote an immigrant entrepreneur from their sample of 170 as saying "black foreigners are not treated like white foreigners in South Africa, most of the South Africans call us names and we are treated like animals". Maharaj (2002:51) argues that xenophobia is widespread in the townships, where immigrants are referred to as "kwerekwere" a disparaging word for African immigrant.

The term xenophobia became widely used in Cape Town and other cities of South Africa in May 2008 when there was widespread of xenophobic attacks. And since then, this notorious challenge to African foreign entrepreneurs is evolving. Landau et al. (2005) argue that immigration is not viewed as a public policy tool that could benefit South Africa. Immigrants and migrants (even the most highly skilled) are more often stereotyped as a threat to the economic and social interests of South Africans.

\subsubsection{Causes of xenophobia in South Africa}

The causes of xenophobia provided by Cronje (2009) include: failure to maintain the rule of law, unemployment and corruption.

- Failure to maintain the rule of law: Cronje (2009) believes that the government is partly responsible for xenophobia in South Africa due to its repeated failures to bring levels of violent crime under control, that contributed to an environment which saw people resort to violence without fear of arrest or successful prosecution. In failing to maintain the rule of law, the government conditioned many poor communities to violent behaviour. The failure to protect communities from criminal elements and to remove those elements allowed criminals to take full advantage of chaos and disorder to rob, rape and loot during the violent uprisings.

- Jealousy: Sylvanus Dixon, a community organizer from Sierra Leone, spoke to the BBC about the causes of xenophobia in his adopted homeland of South Africa. Dixon claimed that fear and jealousy related to employment and income were to blame. "South Africans see foreigners with businesses and they don't know how they got their money", he said. "That's where the jealousy is coming from. That's when the fear becomes xenophobia" (Bordeau, 2010:6). A study conducted in a Port Elizabeth township (Walmer) revealed that jealousy was one of the main reasons for xenophobic violence there. In the Walmer Township, xenophobic violence usually takes place when attackers are jealous of the foreigners' business success (De Jager, 2013).

- Unemployment: Statistics SA (2012:1) reports that $25,5 \%$ of South Africans are failing to secure a proper job with $70,9 \%$ of unemployed youth (15 - 34 years), resulting in $36 \%$ unemployment rate among youth. Moreover, $31,4 \%$ or 3,3 million of the youth aged $25-24$ years are not in employment, education or training (NEET) (Stats SA, 2012:3). It is thus not surprising that scores of youths were able to conduct days and nights of violent campaigns in informal settlements around the country. Unemployment was and still is a direct contributing cause to the violence. In addition, Maharaj (2002:55) argues that xenophobia developed as the vast expectations of the poverty-stricken masses were not met due to the inability of the new democratic government to deliver immediately.

- Corruption: In the public sector, corruption became prevalent under the former president Thabo Mbeki and not much was done to restrain it. The examples of Travelgate, Armsgate, and Oilgate served to create the impression that the South African government was corrupt up to the highest levels of government. Such corruption in turn filtered down into the various government departments at local, provincial, and national level. In the home affairs, social welfare, and law enforcement areas literally tens of thousands of officials were implicated in corrupt dealings (Cronje, 2009).

Cronje (2009) further argues that anger by South Africans at immigrants with illegal documents getting access to services is therefore understandable and was brought about in large part by the failure of the police and the department of home affairs to crack down on fraudulent documents.

\subsubsection{Language}

Hisrich (2010:46) contends that language, sometime considered as the mirror of culture, is composed of verbal and nonverbal components. Messages and ideas are conveyed by the spoken words employed, the voice tone, and the nonverbal actions such as body position, eye contact or gestures. Thus, an entrepreneur or someone on his or her team 
must have command of the language in the country in which business is being conducted. Hisrich (2010:46) believes that this is not only critical for information gathering and evaluation, but also for communication with all involved and ultimately in advertising campaigns as well.

In their research conducted in Finland, Habiyakare, Owusu, Mbare and Landy (2009:61) report that Finnish language emerged to be an obstacle as it was evidently difficult to navigate the Finnish business terrain without it. Consequently, major delays were caused in transacting crucial business.

\subsubsection{Sales fluctuation}

According to Hodgetts and Kuratko (2008:10), the micro-enterprise owner faces sales, and therefore income, fluctuation more than a person employed in a regular job. In some months sales are very high; in others, they drop radically. The owner must balance cash inflows with the outflows so that there is always enough money to meet expenses. Sometimes this requires the owner to take a short-term loan to help the business get through a tough period. Almost every microenterprise has sales fluctuations. For instance, an African foreign micro-enterprise owner selling art work at the V\&A Waterfront may find out that his greatest sales volume occurs during festive season, as the V\&A is South Africa's mostvisited destination, having the highest rate of foreign tourists of any attraction in the country (V\&A. 2013).

\subsubsection{Competition}

Lamb, Hair, McDaniel, Boshoff and Terblanche (2008:100) lament that the concept of competition regards all enterprises or organisations that satisfy the same consumer needs as competitors. Employing this approach, a customer who buys a motor vehicle buys private transport; thus all firms that satisfy the need for privately-owned transport are competitors.

A person may start a business and prosper for three to four years before meeting insurmountable competition. Zimmerer and Scarbourough (2008:303) agree that in the maturity and competition stage of a product life cycle, sales volume continues to rise, but profit margins peak and then begin to drop as competitors enter the market. For instance, micro-enterprises dealing with fruits and vegetables may find that they have lost customers to retail chains such as Fruit $\&$ Veg City.

Tough competition has a great impact in the growth of an enterprise. After conducting research of African immigrant entrepreneurship in Finland, Habiyakare et al. (2009:65) observed that most customers of their respondents were immigrants. Finnish customers were people who had travelled abroad and developed different product tastes. SubSaharan African restaurants had less magnetism to Finnish customers. In this regard competition was mainly limited to a small segment of immigrant customer base. Hence, there were few customers in the market and maintaining them was not an easy task when there were so many enterprises of the same nature.

\subsubsection{Access to finance}

Basu (2011:2) notes that ethnic minority entrepreneurs face greater financial difficulties compared with small enterprises in general, in acquiring credit for business start-up. Ibrahim and Galt (2011:608) contend that the chief difficulty is access to sufficient finance to set up a business, in part, will depend on personal endowments. Zolin and Schlosser (2011:1189) state that immigrants may be disadvantaged by lack of access to human and financial capital, for instance, their credit history may not be simply accessible, making it complicated to apply for credit in their adopted country.

Volery (2007:38) also believes that accumulating the necessary capital for small enterprise creation is one of the major obstacles in the process of venture creation. Aspects such as inner-city locations, extremely competitive market sectors, the absence of a "track record", language difficulties and discrimination, often comprise difficult conditions for obtaining a bank loan.

Piperopulos (2010:144) records that in a number of studies, researchers have found that ethnic minority businesses have never used or had access to business and financial support from banks and other financial institutions and thus had to rely on personal savings and ethnic social resources. This is however surprising as immigrants usually arrive with little savings and often earn their living through unskilled labour paying barely enough to survive (Volery, 2007:39).

Early research by Aldrich and Waldinger (1990:125) explained that immigrants often begin as temporary workers in small enterprises, seeking jobs that provide opportunities to work long hours and accumulate savings. Once their plans for return are postponed, immigrants may have learned skills that present "sunk capital", and provide an incentive to startup as self-employed entrepreneurs. 
Habiyakare et al. (2009:65) report that $74 \%$ of their respondents had saved up their own capital and/or borrowed from their relatives to start their enterprises, while only $7 \%$ took a loan from a bank and the rest had the start-up capital from elsewhere, mainly from investors who were willing to get a share of the business profits. Immigrant entrepreneurs who had been in business for more than 5 years (i.e. 81\%), did not like the notion of borrowing capital from local banks to foster their business expansion; they would rather use own savings for that purpose. Varied reasons were cited but most respondents maintained that banks and the government have not been supportive of the growth of their enterprises in the past.

Nieman, Hough and Nieuwenhuizen (2003:32) state that access to finance is a major challenge to the successful development of small, medium and micro-enterprises (SMMEs) in South Africa. Long lists of ideas are not developed into viable new ventures due to a lack of capital. According to Tengeh et al. (2011) and Claessens (2006), most segments of SMMEs and households lack access to finance, which probably impedes their growth and decreases their welfare. Mugobo and Ukpere (2012) in their study of rural entrepreneurship, report that 59\% of the respondents indicated that access to funding is always a problem, $21 \%$ that financing is a frequent problem, and only $2 \%$ have never had financing challenges. The study observed that financial institutions demand collateral security before providing credit facilities and most entrepreneurs are not able to provide this.

\subsubsection{Business location}

According to Mugobo and Ukpere (2012), most SMMEs still struggle with the shortage of business premises such as offices, warehouses and factories. In their study of rural entrepreneurship they report that $46 \%$ of the respondents indicated that the unavailability of business premises is a difficulty that always occurs, and $32 \%$ reported it occurred frequently.

Even though finding a business location is a constraint, entrepreneurs should be very careful in choosing the appropriate location. Many entrepreneurs make the mistake of taking the first available location without considering if it is suitable to the needs of their business. Mariotti and Glackin (2012:491) posit that the selection of business location can make the difference between success and failure. The key aspects in deciding upon a location are dependent upon the nature of the business and customers.

Fakoti and Garwe (2010:731) believe that location also has impacts on the market potential and growth opportunities of new enterprises. Geographical proximity to either critical buyers or suppliers produces a form of enhanced environmental scanning that enables new firms more easily to identify and exploit growth opportunities in the market. Mariotti and Glackin (2012:492) list the following considerations for deciding on a location: access for customers; access to suppliers; climate and geography; convenience; cost of facilities (rent, construction, etc.); demographics; economic conditions and business incentives; governmental regulations and laws; labour pool; proximity to competitors, and visibility.

\section{Research methodology}

\subsection{Research design}

In the current study, a mixed methods approach was employed. According to Johnson, Onwuegbuzie and Turner (2007:119), a mixed methods study is one that deliberately juxtaposes or combines methods of different types (qualitative and quantitative) to provide a more elaborated understanding of the phenomenon of interest (including its context) and to gain greater confidence in the conclusions generated by the study.

Zikmund, Babin, Carr and Griffin (2010:55) write that descriptive research explains traits, people, groups, organisations or environments. Therefore, descriptive research tries to address who, what, when, where and how questions. This study employed descriptive research as the main question was "What are the challenges in operating micro-enterprises by African foreign entrepreneurs in Cape Town, South Africa?"

\subsection{Targeted population}

Dorsten \& Hotchkiss (2005:28) state that a population should be defined to include individuals we want to describe (e.g. all registered voters), not just those who return a questionnaire. The targeted population for this study was African foreign entrepreneurs who are:

- Operating micro-enterprises within the Cape Town metropolitan area;

- From any country on the African continent. 
Zikmund et al. (2010:119) believe that the unit of analysis for a study indicates what or who should provide the data and at what level of aggregation. Hence, African foreign entrepreneurs who are operating micro-enterprise in Cape Town were the unit of analysis as they would provide required and relevant responses for the study.

\subsection{Sampling technique and sample size}

Convenience sampling (which falls under non-probability sampling) was employed as the researchers realised it would be expensive and time consuming to determine all African foreign entrepreneurs operating micro-enterprises in Cape Town. Hence, the most convenient sample was used. Welman, Kruger and Mitchell (2005:68) put forward that the advantage of non-probability samples is that they are less complicated and more economical in terms of time and financial expenses than probability samples.

Thus far, in South Africa, there is no official estimate of immigrant-owned businesses (Tengeh, 2011:20). Obtaining a reliable estimate of the population size in studies of this class is difficult, thus, drawing a sample size is challenging. Taking into consideration four studies conducted on immigrant entrepreneurship in South Africa, two of which were in Cape Town, (Fatoki \& Patswawairi, 2012; Tengeh et al., 2011; Kalitanyi \& Visser, 2010; Rogerson, 1997), an average sample size of 118.75 was arrived at. Therefore, to ensure satisfactory results, a sample size of 130 respondents was drawn. Two hundred questionnaires were printed; 130 were distributed as self-administered questionnaires and the remainder used as interview guides. A total of 93 completed questionnaires was achieved, through 72 interviews and 21 self-completed returned questionnaires. This gave an overall response rate of $72 \%$. The reason for not achieving a $100 \%$ response was due to disadvantages associated with self-administered questionnaires, including "respondents whose literacy is limited or whose facility with English is restricted will not be able to answer the questionnaire" (Bryman \& Bell, 2011:233).

\subsection{Data gathering and analysis}

The study made use of survey research because it provides a quick, inexpensive, efficient, accurate means of assessing information about a population. Typically, surveys attempt to describe what is happening or learn the reasons for a particular business activity (Zikmund et al. 2010:186).

Data were gathered by using semi-structured personal interviews and questionnaires over a period of six weeks where the researchers and research assistants physically visited African foreign entrepreneurs at their business premises to drop-off research questionnaires or conduct personal interviews. During the data gathering period, the researchers noticed that respondents did not fully complete the research questionnaire when given the responsibility to do it themselves. Thus, the researchers then insisted on personal interviews as a turnaround strategy to achieve a higher response rate.

The data collected from the respondents were captured into SPSS-statistical software. Data were then analysed into useful categories and it is presented in the subsequent section by means of tables followed by a discussion.

\section{Presentation of findings and discussion}

$\begin{array}{ccc} & \text { Table 4.1 Gender of respondents } & \\ \text { Frequency } & \text { Valid Percent } \\ \text { Male } & 64 & 68.8 \\ \text { Female } & 29 & 31.2 \\ \text { Total } & 93 & 100.0\end{array}$

Table 4.1 above illustrates that from 93 respondents who took part in this study 64 were males. A lesser but still significant number of 29 respondents were females. Males are expected to provide shelter, food, clothing and security to their families in the African culture; hence the great number of males involved in entrepreneurial activities.

\begin{tabular}{ccc} 
& Table 4.2 Existence of xenophobia & \\
& Frequency & Valid Percent \\
Yes & 39 & 41.9 \\
No & 54 & 58.1 \\
Total & 93 & 100.0 \\
\hline
\end{tabular}

As presented in Table 4.2, a slight majority of 54 (58.1\%) African foreign entrepreneurs responded "no" when asked if they think that xenophobia still exists in Cape Town meanwhile 39 (41.9\%) responded "yes" to the same question. 
Though the majority of African foreign entrepreneurs reported that they do not think that xenophobia still exists in Cape Town, from personal observation the researchers noted that some of the respondents who opted "no" to the question were unwilling to engage in discussion about this as it was sensitive to them. Respondents who opted "yes" justified their response by putting forward that they still hear stories about their fellow African foreign entrepreneurs being killed and disrespected by South Africans.

Respondents who had been victims of xenophobia stated that it has a negative impact to their businesses as some had to stop operating their enterprises in a particular area or move their enterprises elsewhere. African foreign entrepreneurs who responded that they were never victims of xenophobia also mentioned that xenophobia has a negative impact on a business as they saw fellow foreigners' businesses being looted. According to African foreign entrepreneurs, xenophobia is caused by the combination of local unemployment, discrimination, corruption in government, hatred and jealousy.

Though xenophobia is not a frequent challenge to African foreign entrepreneurs in Cape Town, it is detrimental to their enterprises.

\begin{tabular}{|ccc|}
\hline Table 4.3 Challenges related to lack of knowledge of local languages \\
& Frequency & Valid Percent \\
Yes & 55 & 59.1 \\
No & 38 & 40.9 \\
Total & 93 & 100.0 \\
\hline
\end{tabular}

Table 4.3 shows that a majority of $55(59.1 \%)$ respondents reported that there are some challenges related to the lack of knowledge of local languages while 38 (40.9\%) respondents did not report challenges as a result of lack of knowledge of local languages.

In Cape Town, African foreign entrepreneurs cannot speak Afrikaans; however, most of them are somewhat conversant with Xhosa. Other than English, Afrikaans and Xhosa are the two dominant languages in Cape Town, thus, the lack of knowledge of these two local languages is an obstacle to African foreign entrepreneurs. Sixty-eight (73.1\%) African foreign entrepreneurs agreed that there are benefits to be derived from knowledge of local languages as it makes business to run smoothly.

\begin{tabular}{|ccc|}
\hline \multicolumn{3}{|c|}{ Table 4.4 Covering costs during unfavourable seasons } \\
& Frequency & Valid Percent \\
Yes & 21 & 22.6 \\
Sometimes & 54 & 58.1 \\
No & 18 & 19.4 \\
Total & 93 & 100.0 \\
\hline
\end{tabular}

In answer to the question "Are you able to make enough sales to cover your costs during your unfavourable seasons?" Table 4.4 provides evidence that only 21 (22.6\%) respondents are able to cover their costs during unfavourable seasons, $54(58.1 \%)$ of respondents can sometimes cover their costs during unfavourable seasons meanwhile 18 (19.4\%) respondents cannot. These findings suggest that most African foreign entrepreneurs struggle to cover their operating costs during unfavourable seasons.

Therefore, micro-enterprises are affected by sales fluctuations. Most African foreign entrepreneurs make satisfactory sales in summer. These entrepreneurs believe that sales fluctuation is caused by a combination of poor service, competition, inflation, change in perception and outdated products.

\begin{tabular}{|ccc|}
\hline & Table 4.5 Level of competition & \\
& Frequency & Valid Percent \\
High & 70 & 75.3 \\
Moderate & 23 & 24.7 \\
Total & 93 & 100.0 \\
\hline
\end{tabular}

Table 4.5 shows that a majority of $70(75.3 \%)$ respondents felt that competition is tough while $23(24.7 \%)$ reported that competition is not tough.

There are many businesses of the same nature servicing the same market, making it difficult for some African foreign entrepreneurs to get a satisfactory piece of the pie. However, these entrepreneurs think that competition in their field of operation is fair and that competition presents some benefits, such as management skills, sales increase and customer satisfaction. 


\begin{tabular}{|ccc|}
\hline & Table 4.6 Ease of acquiring funding & \\
& Frequency & Valid Percent \\
Yes & 14 & 15.1 \\
No & 79 & 84.9 \\
Total & 93 & 100.0 \\
\hline
\end{tabular}

Table 4.6 reveals that a large number of $79(98.9 \%)$ respondents acknowledged that it is not easy to get funding to grow their businesses, but, crucially, $14(15.1 \%)$ respondents reported that it is easy to get funding to grow their businesses. Thus access to funds still remains one of the notorious obstacles in entrepreneurship. Abor and Quartery (2010:224) reinforce that small and medium-enterprises (SMEs) are hampered by a number of aspects, including finance.

Obtaining start-up and growth funding is not easy, especially for micro-enterprises ran by Africa foreign entrepreneurs. These entrepreneurs use their own capital or capital from family and friends as they battle to obtain startup and growth funding from banks and financial institutions due to lack of collateral and South African identity documents. Most African foreign entrepreneurs in Cape Town did not get the money they requested for either start-up or to grow their business venture, thus, they still need more funding.

\begin{tabular}{ccc}
\multicolumn{3}{c|}{ Table 4.7 Difficulty in finding a business location } \\
Frequency & Valid Percent \\
Yes & 73 & 78.5 \\
No & 20 & 21.5 \\
Total & 93 & 100.0
\end{tabular}

As can be seen in Table 4.7, a sizable chunk of 73 (78.5\%) respondents reported that finding a business location was difficult. On the other hand, only $20(21.5 \%)$ reported that it was not difficult for them to secure a business location. This correlates with the 31 respondents who found premises in less than 2 months.

Obtaining a business location is a challenge to African foreign entrepreneurs in Cape Town: securing a good business location can take more than 10 years. Nonetheless, it took many African foreign entrepreneurs 1-2 months to secure business premises, and this was achieved through social networks. What determined the choice of business premises for these entrepreneurs was access for customers. These entrepreneurs are happy with their current business premises.

\begin{tabular}{ccc|}
\hline & Table 4.8 Additional challenges faced & \\
& Frequency & Valid Percent \\
Crime & 63 & 67.7 \\
High Rent & 13 & 14.0 \\
Total & 17 & 18.3 \\
\hline
\end{tabular}

Finally, in answer to the question "What are the challenges you are currently faced with in running your enterprise beside the ones mentioned above?" according to Table 4.8, from 30 respondents who answered the above question, 17 respondents cited that high rentals is also a challenge to their businesses while 13 respondents reported that crime is a challenge to them. According to Ikejiaku (2009), the most outstanding solitary fact about crime is that it is committed mostly by teenagers and young adults.

\section{Recommendations and concluding remarks}

The recommendations below are possible approaches on dealing with the obstacles in operating micro-enterprises by African foreign entrepreneurs, to both the entrepreneurs themselves and other stakeholders (government departments). The recommendations are based on the research objectives; therefore they only address the above mentioned key findings.

- Recommendation for government departments dealing with African foreign entrepreneurs

The Department of Trade and Industry (DTI) has a number of agencies that assist SMMEs; this includes coaching and financial assistance. However, most of these agencies do not accommodate immigrant-owned businesses, yet Kalitanyi and Visser (2010) have proven that immigrant entrepreneurs provide employment for locals. The DTI should support SMMEs operated by immigrant entrepreneurs as part of the strategy to combat the high unemployment rate and crime in South Africa.

Immigrant entrepreneurs have taken huge risks in leaving their home country for South Africa, for whatever their reasons. Thus their level of commitment towards entrepreneurship is extremely high as it is their only option to survive in their host country. The Department of Home Affairs should work with the DTI regarding issuing of permits. As a pilot study, these two government departments could develop a programme solely for immigrant entrepreneurs, to include 
granting of business permits and other permits issued by the Home Affairs, financial assistance, and coaching to legal (registered) immigrant-owned businesses that have created sustainable jobs to locals; thereafter, start-up funding could also be considered.

- Recommendation for African immigrant entrepreneurs

African foreign entrepreneurs in Cape Town rent their business premises from locals (Charman, Petersen \& Piper, 2012:58). African foreign entrepreneurs should look at partnering with locals to cut operating costs and to take advantage of government grants aimed at South Africans. A partnership between locals and African foreign entrepreneurs can be a symbiotic relationship as both parties would benefit. African foreign entrepreneurs transfer entrepreneurial skills to locals (Kalitanyi, 2007:107), thus locals would enjoy this benefit from the partnership. African foreign entrepreneurs would enjoy the following benefits from the partnership: reduced crime; reduced xenophobic attacks; reduced operating costs; access to government grants and support as some DTI agencies require locals to be shareholders for funding applications to be considered.

To solve some of the challenges experienced by African foreign entrepreneurs as revealed by this study, entrepreneurial training is required. Therefore, African foreign entrepreneurs should create a networking platform where entrepreneurs can share their challenges and develop possible solutions. This platform can also be useful for informationsharing and a start of long-term business relationships. African foreign entrepreneurs should continuously enrol for business courses to improve their entrepreneurial skills to deal with different challenges in operating micro-enterprises and SMMEs in general.

- Concluding remarks

The main objective of this study was to discover the challenges in operating micro-enterprises by African foreign entrepreneurs in Cape Town. This objective has been successfully accomplished and recommendations were proposed. In addition to the identified barriers to immigrant entrepreneurship, the following challenges came to the fore: high rentals and crime. Immigrant entrepreneurs in Cape Town rent their business premises from locals where they spend a chunk of money on rentals. Crime is also a challenge to these entrepreneurs as locals rob them money or break into their businesses to steal stock.

\section{Suggestions for Further Research}

A comparative research between countries that support immigrant entrepreneurship and countries that do not support immigrant entrepreneurship is needed. This will help government departments that deal with African foreign entrepreneurs and policy makers to understand immigrant entrepreneurship and see its holistic role.

In South Africa, no database of immigrant-owned businesses apparently exists. Thus a study that would profile and show how many immigrant-owned SMMEs by category is required to assist other researchers in the field of immigrant entrepreneurship.

\section{References}

Abor, J. \& Quartey, P. (2010). Issues in SME development in Ghana and South Africa. International Research Journal of Finance and Economics, 39: 218-228. Aldrich, E.H. \& Waldinger, R. (1990). Ethnicity and entrepreneurship. Annual Review of Sociology, 16: 111-35.

Azmat, F. (2010). Exploring social responsibility of immigrant entrepreneurs: Do home country contextual factors play a role? European Management Journal, 28: 377-386.

Basu, A. (2011). From "break out" to "breakthrough": Successful market strategies of immigrant entrepreneurs in the UK. International Journal of Entrepreneurship, 15:1-23.

Bordeau, J. (2010). Xenophobia: The Violence of Fear and Hate. New York: The Rosen Publishing Group.

Bryman, A. \& Bell, E. (2001). Business Research Methods. $3^{\text {rd }}$ ed. New York: Oxford University Press Inc.

Canetti-Nisim, D. \& Pedahzur, A. (2003). Contributory factors to Political Xenophobia in a multi-cultural society: the case of Israel. International Journal of Intercultural Relations, 27:307-333.

Chand, M. \& Ghorbani, M. (2011). National culture, networks and ethnic entrepreneurship: A comparison of the Indian and Chinese immigrants in the US. International Business Review, 20:593-606.

Charman, A., Petersen, L. \& Piper. (2012). From local survivalism to foreign entrepreneurship: the transformation of the spaza sector in Delft, Cape Town. Transformation, 87: 47-73.

Chrysostome, E. \& Lin, X. (2010). Immigrant entrepreneurship: Scrutinizing a promising type of business venture. Thunderbird International Business Review, 52(2):77-82, March/April.

Claessens, S. (2006). Access to Finance Services: A Review of Issues and Public Policy Objectives. World Bank Research Observers, 21(2):208-240, Fall.

Co, M.J., Groenewald, J., Mitchell, B., Nayager, T., van Zyl, J. \& Visser, K. (2006). Entrepreneurship: Fresh perspective. Cape Town: Pearson Education South Africa.

Concise Oxford English dictionary. $11^{\text {th }}$ ed. (2004) Oxford University Press.

Cronje, F. (2008). Xenophobia: Nine causes of the current crisis. Politicsweb: May 20. [Online] http://www.politicsweb.co.za/politicsweb/view/politicsweb len/page71619?oid=89859\&sn=Detail [05 June 2012]

Crush, J. (2000).The Dark Side of Democracy: Migration, Xenophobia and Human Rights in South Africa. International Migration, 38 (6). 
Crush, J. \& Ramachandran, S. (2009). Xenophobia, international migration and human development. Human Development Paper No. 2009/49. United Nations Development Programme, New York.

Cupido, C. (2002). Barriers to entrepreneurship in the Western Cape. Unpublished MTech dissertation, Cape Peninsula University of Technology, Cape Town.

Dalhammar, T. (2004). Voices of entrepreneurship and small business immigrant enterprises in Kista, Stockholm. Unpublished thesis, Royal Institute of Technology, Sweden.

Dana, L-P. (1995). Entrepreneurship in a Remote Sub-Arctic Community. Entrepreneurship Theory and Practice, 20(1):57-72, Fall.

De Jager, S. (2013). Xenophobia 'has roots in jealousy'. The Herald: 06, May 13. [Online] http://www.peherald.com/news/article/14755 [16 October 2013 ]

Dori, I., Honig, B. \& Ginsberg, A. (2006). Transnational entrepreneurship: Toward a unifying theoretical framework. Academy of Management Best Papers Proceedings, Atlanta, GA, August.

Dorsten, L.E. \& Hotchkiss, L. (2005). Research Methods and Society: Foundation of Social Inquiry. Upper Saddle River, New Jersey: Pearson Prentice Hall.

Fatoki, O. \& Garwe, D. (2010). Obstacles to the growth of new SMEs in South Africa: A principal component analysis approach. African Journal Of Business Management, 4(5): 729-738, May.

Fatoki, O. \& Patswawairi, T. (2012). The motivations and obstacles to immigrant entrepreneurship in South Africa. Journal of Social Science, 32(2):133-142.

Habiyakere, E., Owusu R. A., Mbare, O. \& Landy, F.( 2009). Characterising African Immigrant Entrepreneurship in Finland. In: Sigué, S. (ed). Repositioning African Business and Development for the 21st Century. Peer-Reviewed Proceedings of the 10th Annual International Conference Held at the Speke Resort \& Conference Centre, Makerere University Business School, Kampala. [Online] http://www.iaabd.org/pdf//AABD2009Proceedings _Final.pdf. [10 June 2012].

Henn, S. (2012). Transnational entrepreneurs, global pipelines and shifting production patterns. The example of the Palanpuris in the diamond sector. Geoforum, 43: 497-506, January.

Hisrich, R.D. \& Peters, M.P. (1998). Entrepreneurship. $4^{\text {th }}$ ed. New York: McGraw-Hill.

Hodgetts, R.M. \& Kuratko, D.F. (2008). Small Business Management: Essential tools for entrepreneurial success. United States of America: John Wiley \& Sons, Inc.

Human Rights Commission. (1999). Report on the Arrest and Detention of Persons in Terms of the Aliens Control Act. Johannesburg: South African Human Rights Commission.

Hunter, N. \& Skinner, C. (2003). Foreign street traders working in inner city Durban: Local government policy challenges. Urban Forum, 14(4): 309-319.

Ibrahim, G. \& Galt, V. (2011). Explaining ethnic entrepreneurship: An evolutionary economics approach. International Business Review, $20: 607-613$.

Ikejiaku, B-V. (2009). 'Crime', poverty, political corruption and conflict in apartheid and post apartheid South Africa: The implications on economic development. African Journal of Political Science and International Relations, 3(10): 451-459, October.

Johnson, R.B., Onwuegbuzie, A.J. \& Turner, L.A. (2007). Towards a definition of mixed methods research. Journal of Mixed Methods Research, 1(2): 112 133, April.

Kalitanyi, V. (2007). Evaluation of employment creation by African immigrant entrepreneurs for unemployed South Africans in Cape Town. Unpublished MCom dissertation, University of Western Cape, Cape Town.

Kalitanyi, V. \& Visser, K. (2010). African Immigrants in South Africa: Job Takers or Job Creators? South African Journal of Economic and Management Sciences, 13(4): 376-390, September.

Kalupahana, D.J. (1999). Múlamadhyamakakáriká of Nágárjuna: The Philosophy of the Middle Way. Motilal Banarsidass. John Tucker. Middleman. 147148. [Online] www.shsu.edu/.../WinFSHD2Userskmd007ArticlesMiddlemenMinorities.pdf [22 August 2012]

Lamb, C.W, Hair, J.F, McDaniel, C., Boshoff, C. \& Terblanche, N.C. (2008). Marketing. 3rd South African ed. Southern Africa: Oxford University Press.

Landau, L.B., Ramjathan-Keogh, K. \& Singh, G. (2005). Xenophobia in South Africa and Problems Related to it. Johannesburg: University of the Witwatersrand.

Mariotti, S. \& Glackin, C. (2012). Entrepreneurship \& Small Business Management. New Jersey. Prentice Hall.

Meijerink, F., Mudde, C., \& Van Holsteyn, J. (1998). Right-wing extremism. Acta Politica, 2, 165-178.

Mugobo, V.V. \& Ukpere, W.I. (2012). Rural entrepreneurship in the Western Cape: Challenges and opportunities. African Journal of Business Management Vol. 6(3): 827-836, January.

Ngwema, S. (1998). Interview: Surviving by 'hook or by crook'. Crossing, 2(1): February

Nieman, G., Hough, H. \& Niewenhuizen, C (eds). (2003). Entrepreneurship: A South African Perspective. $2^{\text {nd }}$ ed. Pretoria: Van Schaik Publishers.

Piperopoulos, P.( 2010). Ethnic minority businesses and immigrant entrepreneurship in Greece. Journal of Small Business and Enterprise Development, 17(1): 139-158.

Rogerson, C. M., (1997): International Migration, Immigrant Entrepreneurs and South Africa's Small Enterprise Economy, Migration Policy Series No. 3, The Southern Africa Migration Project, Cape Town

South Africa. (1996). National Small Business Act No. 102 of 1996. Pretoria: Government Printer.

South Africa. (2003). National Small Business Amendment Act No. 26 of 2003. Pretoria: Government Printer.

Statistics SA. (2012). Census 2011. Municipal Report: Western Cape. [Online] http://www.statssa.gov.za/Census2011/Products/WC_Municipal_Report.pdf [07 June 2012]

Tengeh, R.K. (2011). A business framework for the effective start-up and operation of African immigrant-owned businesses in the Cape Town Metropolitan area, South Africa. Unpublished DTech thesis, Cape Peninsula University of Technology, Cape Town.

Tengeh, R.K. (2013). Advancing the case for the support and promotion of African immigrant-owned businesses in South Africa. Mediterranean Journal of Social Sciences, 4(2): 347-359.

Tengeh, R.K., Ballard, H.B \& Slabbert, A.S. (2011). Financing the Start-up and Operation of Immigrant-owned Businesses: the path taken by African Immigrants in the Cape Town Metropolitan Area of South Africa. Munich Personal RePEc Archive Paper No. 38405.

V\&A Waterfront. (2013). History[Online] http://www.waterfront.co.za/vanda/history [30 November 2013]

Venter, R., Urban, B. \& Rwigema, H. (2008). Entrepreneurship: theory in practice. $2^{\text {nd }}$ ed. Southern Africa: Oxford.

Volery, T. (2007). Ethnic entrepreneurship: A theoretical framework. In L-P. Dana (Ed.) Handbook of research on ethnic minority entrepreneurship: A coevolutionary view on resource management ed. Edward Elgar Publishing Cheltenham: 30 - 41.

Welman, C., Kruger, F. \& Mitchell, B. (2005). Research Methodology. $3^{\text {rd }}$ ed. Southern Africa: Oxford University Press.

Zikmund, W. G., Babin, B.J., Carr, J.C. \& Griffin, M. (2010). Business Research Methods. $8^{\text {th }}$ ed. Canada: South-Western Cengage.

Zimmerer, T.W. \& Scarborough. (2008). Essentials of Entrepreneurship and Small Business Management. $5^{\text {th }}$ ed. Upper Saddle River, New Jersey: Pearson Prentice Hall.

Zolin, R. \& Schlosser, F.( 2011). The role of immigrant entrepreneurs in international new ventures. AGSE International Entrepreneurship Research Exchange, Swinburne University of Technology, Melbourne, Vic: 1187-1198. 